EVOLUTIONARY BIOLOGY OF

Parasites 


\section{MONOGRAPHS IN POPULATION BIOLOGY}

EDITED BY ROBERT M. MAY

1. The Theory of Island Biogeography, by Robert H. MacArthur and Edward O. Wilson

2. Evolution in Changing Environments: Some Theoretical Explorations, by Richard Levins

3. Adaptive Geometry of Trees, by Henry S. Horn

4. Theoretical Aspects of Population Genetics, by Motoo Kimura and Tomoko Ohta

5. Populations in a Seasonal Environment, by Stephen D. Fretwell

6. Stability and Complexity in Model Ecosystems, by Robert M. May

7. Competition and the Structure of Bird Communities, by Martin Cody

8. Sex and Evolution, by George C. Williams

9. Group Selection in Predator-Prey Communities, by Michael E. Gilpin

10. Geographic Variation, Speciation, and Clines, by John A. Endler

11. Food Webs and Niche Space, by Joel E. Cohen

12. Caste and Ecology in the Social Insects, by George F. Oster and Edward O. Wilson

13. The Dynamics of Arthropod Predator-Prey Systems, by Michael P. Hassell

14. Some Adaptations of Marsh-nesting Blackbirds, by Gordon H. Orians

15. Evolutionary Biology of Parasites, by Peter W. Price 


\title{
EVOLUTIONARY BIOLOGY OF Parasites
}

\author{
PETER W. PRICE
}

PRINCETON, NEW JERSEY

PRINCETON UNIVERSITY PRESS

1980 
Copyright (C) 1980 by Princeton University Press Published by Princeton University Press, Princeton, New Jersey In the United Kingdom: Princeton University Press, Guildford, Surrey

ALL RIGHTS RESERVED

Library of Congress Cataloging in Publication Data will be found on the last printed page of this book This book has been composed in Linotype Baskerville Clothbound editions of Princeton University Press books are printed on acid-free paper, and binding materials are chosen for strength and durability

Printed in the United States of America by Princeton University Press, Princeton, New Jersey 